\title{
Miskonsepsi gaya gesek pada mahasiswa
}

\author{
Yuant Tiandho ${ }^{1}$ \\ ${ }^{1}$ Jurusan Fisika, Universitas Bangka Belitung, Kep. Bangka Belitung 33172, Indonesia \\ E-mail: yuant@ubb.ac.id
}

Received: 0612 2017. Revision: 2901 2018. Accepted: 01022018

\begin{abstract}
Abstrak
Pada makalah ini dilakukan evaluasi pemahaman mahasiswa tingkat awal terkait konsep gaya gesek yang telah mereka pelajari ketika di sekolah menengah atas. Berdasarkan pengujian awal dapat diketahui bahwa kebanyakan mahasiswa masih mengalami miskonsepsi terkait konsep gaya gesek, khususnya dalam konsep gaya gesek statis. Tingginya miskonsepsi mahasiswa terkait gaya gesek statis disebabkan oleh banyaknya literatur yang merumuskan gaya gesek statis secara tidak tepat yaitu sebagai perkalian dari koefisien gesek statis dengan gaya normalnya yang bernilai konstan. Selain itu, ungkapan matematis dari gaya gesek statis yang menggunakan simbol ketidaksamaan meningkatkan potensi miskonsepsi karena dirasa lebih sulit oleh mahasiswa seperti dinyatakan dalam penelitian Handhika, et al. (2015). Melalui pengajaran dengan rumusan gaya gesek statis yang benar menggunakan metode analogi, mahasiswa dapat memahami konsep gaya gesek dan implikasinya secara lebih baik dari sebelumnya. Sehingga dari penelitian ini diharapkan guru menggunakan buku teks yang memberikan deskripsi yang benar tentang gaya gesek.
\end{abstract}

Kata Kunci: analogy; gaya gesek; mekanika klasik; miskonsepsi

\section{Frictional force misconceptions on undergraduate student}

\begin{abstract}
In this paper evaluation of the comprehension of undergraduate student at first level related to the frictional forces concept that has been studied in their senior high school has been done. Based on the preliminary test it can be seen that most students are still experiencing misconceptions related to the frictional force concept, especially in the static frictional force. The high misconceptions of students on static friction caused by the abundance of literature that formulates static friction improperly as a multiplication of static friction coefficients with its normal force and the value always constant. In addition, the mathematical expression of static frictional force using symbols of inequality increases the risk of misconceptions because it is more abstract as stated by Handhika et al. (2015). Through lectures with use right formulation of the static frictional forces by using analogical method, the students can understand the frictional forces concepts and its implication better than ever. So from this research is expected to teachers use textbook which give right description about frictional force.
\end{abstract}

Keywords: alalogy; classical mechanics; frictional forces; misconception

\section{PENDAHULUAN}

Miskonsepsi atau kadang disebut dengan konsepsi alternatif merupakan suatu struktur kognitif yang dipegang teguh tetapi berbeda dengan pemahaman konsep yang sesungguhnya (menurut para ahli) dan mungkin saja dapat ikut mengontaminasi ketika dilakukan konstruksi pengetahuan baru (Hammer, 1996). Miskonsepsi berbeda dengan kekurangpahaman (preconception) terhadap suatu konsep atau pembelajaran karena kekurangpahaman dapat diatasi dengan instruksi dan pembelajaran selanjutnya. Kekurangpahaman dapat dipandang sebagai suatu "gagasan sebelum instruksi". Miskonsepsi dapat terjadi karena berbagai macam hal diantaranya: intuisi yang 
tidak tepat, materi yang memang abstrak, dan sulit dimengerti, informasi yang keliru dari teman, guru, bahkan sumber-sumber pembelajaran (Clement, et al., 1989).

Permasalahan besar yang mungkin muncul akibat adanya miskonsepsi adalah lambatnya pemahaman terhadap konsepkonsep baru yang terintegrasi dengan pengetahuan yang mengalami miskonsepsi dan semakin menyimpangnya pemahaman konsep baru tersebut karena miskonsepsi cenderung tidak disadari (Hasan, et al., 1999). Tentu saja hal ini kemudian akan menghambat siswa untuk mengikuti perkembangan ilmu pendidikan yang telah mengarah pada kemampuan berpikir tingkat tinggi (Trianggono, 2017).

Pada dasarnya miskonsepsi dapat terjadi pada berbagai hal (Grayson, 2004). Dalam bidang sains, diketahui bahwa seiring dengan peningkatan penelitian terkait topik kependidikan semakin tinggi pula jumlah miskonsepsi siswa dalam berbagai usia yang terdeteksi dalam spektrum konsep yang semakin luas (Yuruk, 2007). Sejauh ini berbagai penelitian juga menunjukkan bahwa miskonsepsi dialami oleh siswa dari berbagai negara dan budaya bahkan pada berbagai rentang usia dan tingkat pendidikan (dasar, menengah, dan sarjana) pada semua bidang sains (Pinarbasi, et al., 2006; Syuhendri, et al., 2014). Beberapa metode pembelajaran yang dikembangkan untuk mengatasi permasalahan miskonsepsi diantaranya adalah metode analogi (Lin \& Singh, 2011; Apriliani, et al., 2015) dan metode 5 E: engagement, exploration, explanation, elaboration, dan evaluation (Cepni, et al., 2010; Balci \& Cakiroglu, 2006)

Fisika merupakan salah satu bidang sains yang seringkali dianggap sulit dan membutuhkan perhatian lebih dalam proses pembelajaran (Handhika, et al., 2015). Hanya ada sedikit prinsip-prinsip dasar fisika yang terangkum menjadi bentuk matematika yang sederhana. Selain pemahaman konsep melalui proses eksperimen dan penganalogian, pembelajaran fisika juga membutuhkan pembongkaran prinsip-prinsip dasar melalui analisis matematis serta prediksi implikasi yang mungkin saja muncul (Lin \& Singh, 2011; Redish, et al., 2006). Meskipun matematika bukanlah segalanya dalam pembelajaran fisika tetapi penggunaan simbol matematis serta pengaruh bahasa intuisi matematis merupakan hal yang tidak dapat dihindari dalam proses pembelajaran fisika. Pemahaman bahasa matematika dan intuisi yang salah akan menjadi salah satu penyebab munculnya miskonspesi (Handhika, et al., 2015).

Gaya gesek merupakan salah satu topik penting dalam mempelajari materi mekanika. Meskipun gaya gesek bukanlah salah satu dari gaya fundamental (Tiandho, 2016) tetapi dengan adanya pemahaman konsep gaya gesek maka teori-teori fisika yang dipelajari akan terasa lebih realistis. Pada umumnya, banyak teori dalam fisika disajikan dengan asumsi tanpa gaya gesek dan hal tersebut kurang sesuai dengan pengalaman sehari-hari, misalkan saja dalam peristiwa gerak jatuh bebas, gerakan piston, dan osilasi pendulum sederhana. Sehingga dengan adanya konsep gesekan diharapkan tidak ada lagi yang menganggap hukum fisika hanya berlaku untuk dunia yang ideal di laboratorium. Lebih jauh, hal ini juga bertujuan untuk meminimalisir pendapat yang menyatakan bahwa ilmu yang dipelajari di sekolah bersifat abstrak dan jauh dari kehidupan nyata (Besson, 2013).

Saat ini telah cukup banyak model yang digunakan untuk mendeskripsikan gesekan antar permukaan benda (Blass, Albrecht, Bozna, Wenz, \& Bennewitz, 2015; Kudra \& Awrejcewicz, 2016). Tetapi umumnya, gaya gesek yang dipelajari di sekolah menengah dan tingkat awal perguruan tinggi adalah gaya gesek yang memenuhi model yang diajukan oleh Coulomb dan Amontons (Popova \& Popov, 2015). Dalam model tersebut dinyatakan bahwa: (1) besar gaya gesek bergantung pada berat benda (atau gaya normal), (2) besar gaya gesek tidak bergantung pada luas permukaan kontak, dan (3) gaya gesek kinetis tidak bergantung pada kecepatan. Salah satu ciri khas dari model yang diajukan oleh Coulomb adalah dilakukan pemisahan antara gaya gesek statis dengan gaya gesek kinetis (gaya gesek dinamis) (Amontons, 1699; Coulomb, 1773). Gaya gesek statis adalah gaya gesek yang bekerja ketika benda belum bergerak sedangkan gaya gesek kinetis adalah gaya gesek yang bekerja untuk benda yang telah bergerak (De Ambrosis, Malgieri, Mascheretti, \& Onorato, 2015). Karena gaya gesek statis bekerja untuk benda yang diam maka berdasarkan hukum I 
Newton, besar gaya gesek statis haruslah sama dengan gaya "luar" yang bekerja pada benda sehingga terpenuhi syarat $\sum F=0$. Dengan demikian dapat disimpulkan bahwa nilai gaya gesek statis bergantung pada gaya "luar" dan tidak bernilai konstan. Adapun untuk gaya gesek kinetis nilainya relatif konstan dan biasanya nilainya lebih kecil dari gaya gesek statis maksimum. Untuk memenuhi syarat tersebut, maka secara matematis gaya gesek statis dan kinetis masing-masing dituliskan sebagai (Young, Freedman, \& Ford, 2012),

$$
\begin{aligned}
& f_{s} \leq \mu_{s} N \\
& f_{k}=\mu_{k} N
\end{aligned}
$$

dengan $f_{s}$ dan $f_{k}$ masing-masing adalah gaya gesek statis dan kinetis, $\mu_{s}$ dan $\mu_{k}$ masingmasing adalah koefisien gesek statis dan kinetis, dan $N$ adalah gaya normal yang bekerja pada benda.

Topik gaya gesek dalam pembelajaran fisika merupakan salah satu topik yang menarik untuk dikaji tingkat miskonsepsinya (Sharma \& Sharma, 2007; Chia, 1996). Hal ini dikarenakan terdapat beberapa perbedaan kesimpulan terkait tingginya miskonsepsi dalam gaya gesek. Di dalam penelitian yang telah dilakukan oleh Hasan (1999) diperoleh hasil bahwa materi gaya gesek merupakan materi yang kemungkinan miskonsepsinya tidak cukup besar. Tetapi di dalam penelitian yang dilakukan oleh Lin dan Singh (2011) disimpulkan bahwa terdapat beberapa kemungkinan miskonsepsi yang akan muncul dalam materi gaya gesek. Tingginya potensi miskonsepsi gaya gesek terletak pada definisi gaya gesek statis dan potensi miskonsepsi tersebut tidak dikaji dalam penelitian yang dilakukan oleh Hasan (1999). Kebanyakan siswa memiliki anggapan bahwa gaya gesek statis selalu bernilai maksimum karena siswa memiliki kesulitan dengan definisi ketidaksamaan matematis yang berkaitan dengan besar gaya gesek statis terhadap gaya normal. Hal ini kemungkinan disebabkan oleh kosakata pengantar fisika dan bagaimana hal tersebut ditafsirkan oleh siswa (Ortiz, et al., 2003). Selain itu evaluasi ini dibutuhkan karena saat ini banyak buku fisika (Esvandiari, 2007; Sugiyono, 2009; Izati, 2014; Supomo, 2007) dan situs belajar online yang membahas materi gaya gesek secara kurang tepat, khususnya dalam gaya gesek statis. Literatur-literatur tersebut menyajikan rumusan matematis gaya gesek statis secara umum sebagai nilai maksimum gaya gesek statisnya yaitu sebagai $f_{s}=\mu_{s} N$. Implikasi dari penggunaan rumusan ini dikhawatirkan dapat membuat siswa menafsirkan gaya gesek statis akan bernilai konstan tidak bergantung berapa pun gaya yang dikerjakan pada suatu benda. Disamping itu, diharapkan hasil penelitian ini menjadi evaluasi dari buku-buku teks dan website yang digunakan sebagai sumber rujukan dalam proses pembelajaran fisika.

\section{METODE}

Subjek yang diamati dalam melakukan penelitian ini adalah mahasiswa tingkat awal pada Fakultas Teknik Universitas Bangka Belitung sejumlah 30 orang yang dipilih secara acak. Mahasiswa-mahasiswa tersebut berasal dari sekolah menengah atas yang berbeda-beda di daerah Provinsi Bangka Belitung. Untuk melihat adanya miskonsepsi tentang gaya gesek yang telah mereka pelajari di sekolah menengah atas maka diajukan beberapa pertanyaan terkait definisi dan perhitungan gaya gesek sebelum mereka mempelajari konsep tersebut di tingkat universitas.

Adapun pertanyaan pre-test yang diajukan sebagai berikut:

1. Berdasarkan kondisi gerak benda gaya gesek dibagi menjadi? Sebutkan!

2. Apa yang disebut dengan gaya gesek statis? Tuliskan rumusan matematisnya

3. Apa yang disebut dengan gaya gesek kinetis? Tuliskan rumusan matematisnya.

4. Suatu balok bermassa $10 \mathrm{~kg}$ didorong dengan gaya sebesar $F$ seperti pada gambar di bawah.

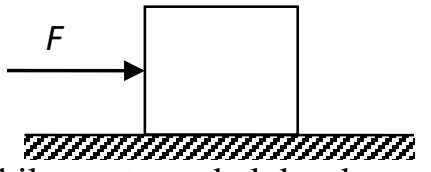

Apabila antara balok dengan lantai terdapat gaya gesek, dimana koefisien gesekan statis $\mu_{s}=0,8$ sedangkan koefisien gesekan kinetis $\mu_{k}=0,2$ maka gambarkan arah gaya gesek dan tentukan besarnya ketika $\left(g=10 \mathrm{~m} / \mathrm{s}^{2}\right)$ :

a. Didorong dengan gaya $F$ yang besarnya $50 \mathrm{~N}$

b. Didorong dengan gaya $F$ yang besarnya $100 \mathrm{~N}$ 


\section{Jurnal Pendidikan Fisika dan Keilmuan (JPFK), 4 (1), 2018 - 4}

Yuant Tiandho

Dari hasil jawaban yang diperoleh maka dapat ditentukan konsep apakah yang dominan mengalami miskonsepsi berdasarkan jumlah jawaban yang tidak tepat. Setelah itu mahasiswa-mahasiswa tersebut diberikan materi terkait gaya gesek sesuai dengan definisi fisis dan matematis yang benar melalui metode analogi dengan hukum Newton II. Secara terperinci metode analogi tersebut dilakukan dengan cara mengembalikan hasil perhitungan gaya gesek statis agar diperoleh kondisi diam. Untuk melihat keefektifan pemberian konsep tersebut juga dilakukan post-test dengan pertanyaan sebagai berikut:

1. Apa yang disebut dengan gaya gesek statis? Tuliskan rumusan matematisnya.

2. Apa yang disebut dengan gaya gesek kinetis? Tuliskan rumusan matematisnya

3. Suatu balok bermassa $10 \mathrm{~kg}$ berada di atas bidang miring dengan sudut $30^{\circ}$ dan awalnya dalam kondisi diam didorong dengan gaya $F$ seperti pada gambar.

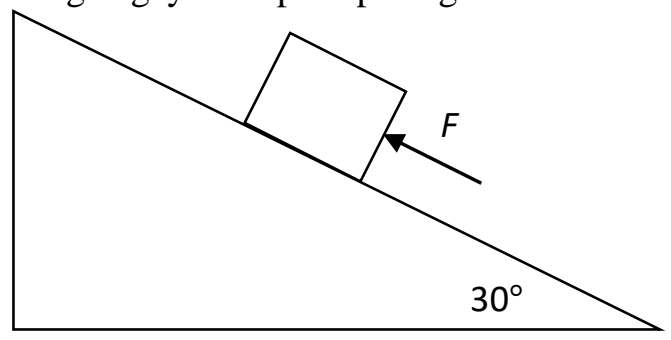

Apabila diketahui koefisien gesekan statis antara balok dengan permukaan adalah $\mu_{s}=0,8$ sedangkan koefisien gesekan kinetis adalah $\mu_{k}=0,2$ maka gambarkan arah gaya gesek dan tentukan besarnya ketika:

a. Didorong dengan gaya $F=0 \mathrm{~N}$.

b. Didorong dengan gaya $F=100 \mathrm{~N}$

c. Didorong dengan gaya $F=200 \mathrm{~N}$

d. Tentukan besarnya gaya dorong $F$ untuk kondisi tepat balok akan bergerak

Tingkat keberhasilan pelurusan konsep ditentukan berdasarkan analisis jawaban yang benar.

\section{HASIL DAN PEMBAHASAN}

Hasil pre-test uji miskonsepsi tentang gaya gesek disajikan dalam Tabel 1 dan untuk contoh jawaban mahasiswa untuk soal nomor 1 - 3 ditunjukkan pada Gambar 1 . Berdasarkan hasil pre-test tersebut dapat dilihat bahwa soal dengan tingkat kesalahan tertinggi terjadi pada soal nomor 2 dan 4(b). Melalui soal nomor 1, terkait dengan jenis gaya gesek, seluruh mahasiswa memberikan jawaban yang tepat. Hasil ini mengindikasikan bahwa mereka telah mengetahui jenis-jenis gaya gesek dengan baik. Sehingga melalui hasil tersebut dapat dinyatakan bahwa mahasiswa-mahasiswa yang diuji dalam penelitian telah mempelajari materi gaya gesek sebelumnya pada sekolah tingkat menengah. Tetapi pada soal nomor 2 ketika mereka diminta untuk mendefinisikan jenis gesek statis mayoritas jawaban memberikan definisi yang tidak tepat pada rumusan matematisnya. Pada dasarnya, jawaban yang diberikan telah memenuhi definisi gaya gesek statis secara fisis tetapi pada definisi matematis hampir seluruh mahasiswa memberikan jawaban $f_{s}=\mu_{s} N$. Hanya ada dua mahasiswa yang dapat memberikan definisi gaya gesek statis secara tepat, baik secara fisis maupun rumusan matematisnya. Seperti dinyatakan oleh Clement et al. (1989) kesalahan yang bersifat umum dalam penelitian ini kemungkinan besar disebabkan oleh informasi yang keliru dari teman, guru, atau sumber rujukan belajar lain. Hal ini didukung oleh adanya komplain yang dilakukan oleh beberapa mahasiswa sembari menunjukkan bukti rumusan matematis seperti yang ada di sumber belajar yang bentuk rumusannya tidak tepat. Selain itu, kemungkinan mahasiswa juga belum terbiasa dengan rumusan matematis yang menggunakan tanda ketidaksamaan sehingga hal ini semakin memicu peningkatan miskonsepsi. Mahasiswa-mahasiswa akan lebih menyukai tampilan rumus yang sederhana sehingga mereka hanya mengingat definisi nilai maksimum dari gaya gesek statis (Lin \& Singh, 2011).

Hasil yang berbeda terjadi pada soal nomor 3. Ketika mahasiswa diminta untuk mendefinisikan gaya gesek kinetis baik secara fisis dan matematis seluruh mahasiswa memberikan jawaban yang tepat. Hal ini memberikan indikasi bahwa mahasiswa-mahasiswa tidak mengalami miskonsepsi untuk materi ini dan hasil ini sesuai dengan penelitian yang dilakukan oleh Hasan (1999) yang melakukan penelitian dengan fokus pada gaya gesek kinetis. Secara matematis, rumusan gaya gesek kinetis relatif lebih sederhana dibanding gaya gesek statis 
karena menggunakan ungkapan persamaan bukan pertidaksamaan. Sehingga hal ini juga mendukung hasil penelitian yang menyatakan bahwa ungkapan matematis yang rumit akan meningkatkan probabilitas terjadinya miskonsepsi (Handika et. al, 2015).

\section{PRE-TEST}

1. Berdasarkan kondisi gerak benda gaya gesek dibagi menjadi? Sebutkan! Jawaban: Gaya Gesek Statis dan Gaya Gesek Kinetis

2. Apa yang disebut dengan gaya gesek statis? Tuliskan rumusan matematisnya. Jawaban: Gaya gesek statis adalah gaya yang bekerja pada benda Rumus matematis : $f_{s}=\mu_{s} . N$

3. Apa yang disebut dengan gaya gesek kinetis? Tuliskan rumusan matematisnya. Jawaban: Ketika sebuah benda bergerak sepanjang permukaan yang kasar, gaya gesekan kinetik bekerja dengan berlawanan arah thd kecepatan benda. GayaGesek kinetjik bekerja pada benda yg bergerak ( $f_{k}: \mu_{k} . N$ )

Gambar 1. Sampel hasi jawaban pre-test mahasiswa untuk nomor 1-3

Implikasi dari penggunaan definisi matematis yang kurang tepat pada penentuan definisi gaya gesek statis akan memberikan dampak yang sangat signifikan ketika diberikan persoalan tentang penerapan gaya gesek statis seperti dilakukan pada soal nomor 4(a). Tentu saja, dengan menggunakan definisi matematis gaya gesek statis sebagai $f_{s}=\mu_{s} N$ maka kebanyakan mahasiswa akan menjawaban soal nomor 4(a) dengan tidak tepat pula. Rumusan matematis tersebut akan membuat hasil.

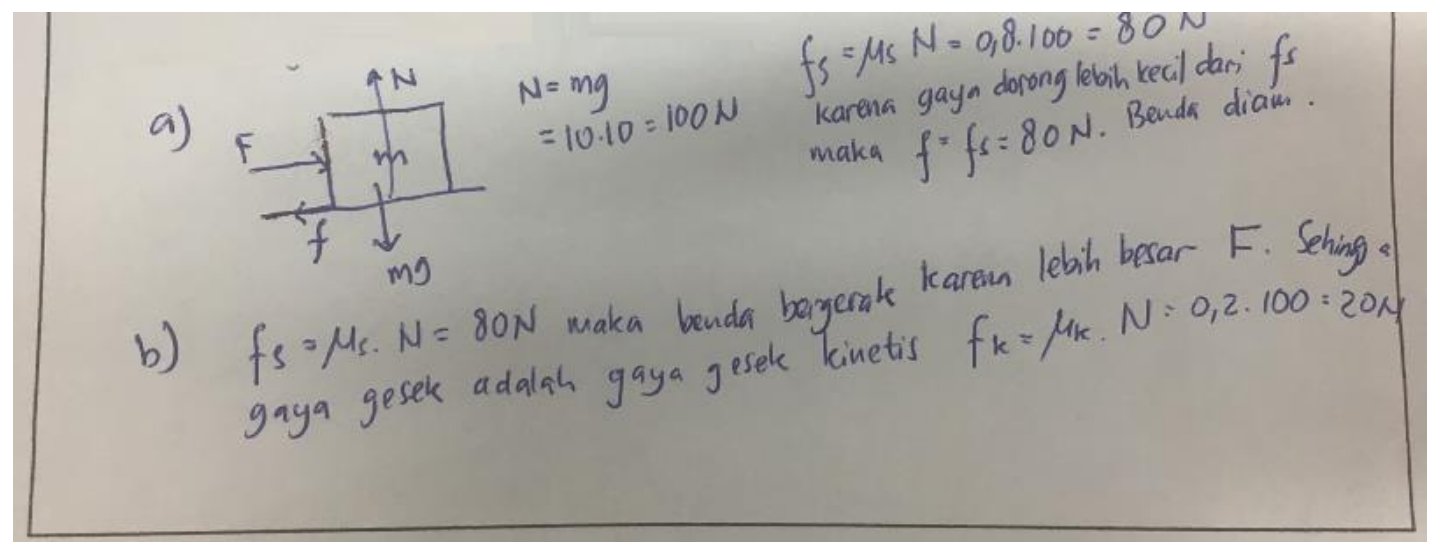

Gambar 2. Sampel hasil jawaban pre-test mahasiswa untuk nomor 4(a)

Tabel 1. Hasil pre-test materi gaya gesek sebelum diberikan pelurusan konsep

\begin{tabular}{ccc}
\hline No. Soal & Jumlah Benar & Jumlah Salah \\
\hline 1 & 30 & 0 \\
2 & 2 & 28 \\
3 & 30 & 0 \\
$4($ a) & 1 & 29 \\
$4(\mathrm{~b})$ & 26 & 4 \\
\hline
\end{tabular}

Berbeda dengan gaya gesek statis, seluruh mahasiswa yang diuji dalam penelitian ini dapat memberikan jawaban yang tepat terkait gaya gesek kinetis (dapat 


\section{Jurnal Pendidikan Fisika dan Keilmuan (JPFK), 4 (1), 2018 - 6}

Yuant Tiandho

dilihat seluruh jawaban pada soal nomor 3 benar). Sehingga berdasarkan hasil tersebut dapat dikatakan bahwa mayoritas mahasiswa tidak mengalami masalah ketika mendefinisikan gaya gesek kinetis. Kesimpulan ini juga diperkuat oleh soal nomor 4(b) dimana hampir keseluruhan mahasiswa memberikan jawaban yang benar. Hanya ada 4 jawaban yang salah, itupun juga disebabkan oleh kesalahan-kesalahan perhitungan yang tidak begitu mengganggu konsep gaya gesek kinetis yang telah mereka pelajari.

Setelah mengamati tingginya tingkat miskonsepsi pada materi gaya gesek statis kemudian dilakukan pelurusan konsep melalui pemberian materi gaya gesek dengan menitikberatkan pada gaya gesek statis sesuai dengan rumusan yang benar. Pemberian materi dilakukan melalui metode analogi dengan hukum Newton II. Pemilihan materi hukum Newton II sebagai sumber penganalogian karena materi tersebut sebelumnya telah dipelajari oleh mahasiswa. Selain itu, hukum Newton II juga merupakan materi fundamental yang mendasari berbagai kasus mekanika termasuk juga dengan gaya gesek. Metode penganalogian dipilih karena metode ini cukup efektif dibandingkan dengan metode instruksional lainnya dan relatif mudah (Bryce \& MacMillan, 2005). Pada Gambar 3 disajikan materi pembahasan yang digunakan dalam penelitian ini. Secara terperinci metode penganalogian difokuskan pada penerapan gaya gesek statis konstan atau bernilai maksimum maka akan diperoleh kondisi benda mengalami percepatan yang bernilai negatif atau justru bergerak berlawanan arah dengan gaya dorong. Sehingga agar tercapai kondisi diam maka digunakan penyusunan logika bahwa nilai gaya gesek haruslah sama dengan gaya netto yang diberikan.

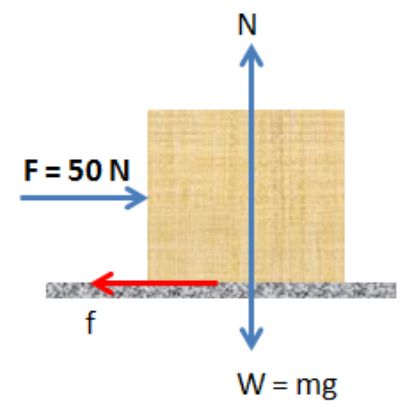

$$
\begin{gathered}
\sum F_{y}=0 \rightarrow N=W \\
f_{s \max }=\mu_{s} N=0,8 \times 100=80 \mathrm{~N} \\
\text { Karena gaya gesek statis lebih besar } \\
\text { dari gaya dorong maka benda diam. } \\
\text { Lalu apakah nilainya } 80 \mathrm{~N} \text { ? } \\
\sum F_{x}=m a \\
F-f=m a \\
a=\frac{50-80}{10}=-3 \mathrm{~m} / \mathrm{s}^{2} ?
\end{gathered}
$$

Agar diam maka $a=0$ sehingga:

$$
f=F=50 \mathrm{~N}
$$

Gambar 3. Materi gaya gesek statis melalui penganalogian dengan hukum Newton III

Untuk menguji keberhasilan konsep yang diberikan maka mahasiswa diberikan post-test yang hasilnya ditunjukkan oleh Tabel 2. Berdasarkan hasil post-test tampak ada peningkatan jawaban yang benar ketika mahasiswa kembali diberikan persoalan terkait gaya gesek statis (ditunjukkan oleh soal nomor 3(a) dan 3(b) pada Gambar 4). Adapun kesalahan yang muncul pada perhitungan mayoritas disebabkan oleh kesalahan analisis diagram gaya dan bukan pada definisi gaya gesek itu sendiri. Begitu pula dengan jawaban pada soal nomor 3(c) yang merupakan persoalan gaya gesek kinetis dan soal nomor 3(d) yang mengujikan nilai gaya gesek statis maksimum. Kesalahan dari kedua persoalan tersebut lebih disebabkan oleh kesalahan-kesalahan perhitungan analisis gaya secara umum, terutama analisis gaya pada bidang miring. Berdasarkan hasil tersebut maka dapat dikatakan bahwa metode analogi cukup efektif untuk menghindari miskonsepsi dalam materi gaya gesek. Ogborn et. al. (1996) telah menyatakan bahwa metode analogi merupakan suatu cara untuk memperoleh pengetahuan baru dengan "bekal" yang ada. Seringkali analogi seringkali sangat tersebunyi bahkan sering tidak tampak untuk menjadi analogi lain seperti pada konsep suara dan cahaya yang keduanya adalah gelombang. Penggunaan analogi dalam proses belajar mengajar akan membantu siswa untuk mengembangkan 
pemahaman terkait fenomena abstrak atau suatu fenomena yang memiliki rumusan matematis sulit karena metode ini menggunakan contoh yang lebih nyata. Hasil ini juga sekaligus menjawab pernyataan yang diajukan oleh Bryce \& Millan (2005) yang meragukan penggunaan metode analogi dalam proses pembelajaran yang melibatkan kasus numerik.

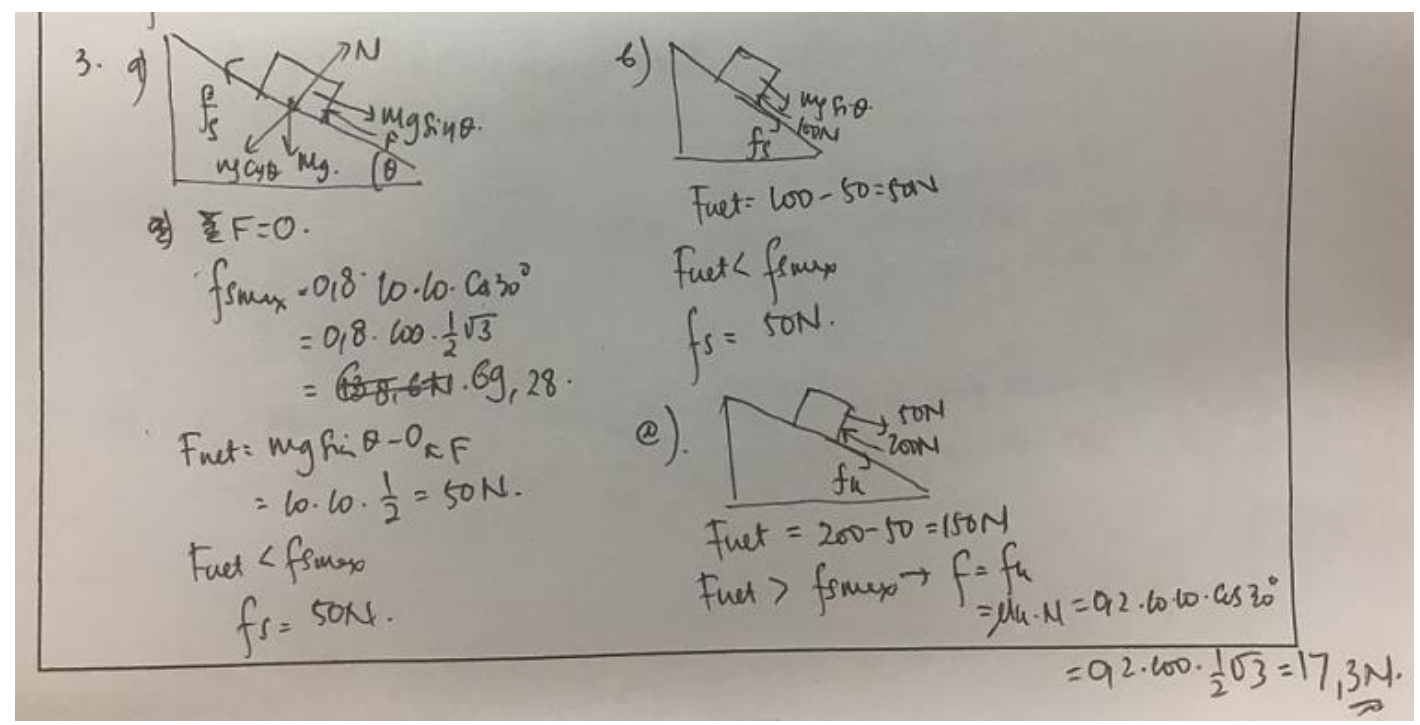

Gambar 2. Sampel hasil jawaban pre-test mahasiswa untuk nomor 3(a-d)

Tabel 2. Hasil post-test materi gaya gesek setelah diberikan pelurusan konsep

\begin{tabular}{ccc}
\hline No. Soal & Jumlah Benar & Jumlah Salah \\
\hline 1 & 30 & 0 \\
2 & 30 & 0 \\
$3 \mathrm{a}$ & 28 & 2 \\
$3 \mathrm{~b}$ & 27 & 3 \\
$3 \mathrm{c}$ & 27 & 3 \\
$3 \mathrm{~d}$ & 25 & 5 \\
\hline
\end{tabular}

\section{SIMPULAN}

Berdasarkan pembahasan di atas dapat disimpulkan bahwa mayoritas mahasiswa uji dalam penelitian ini mengalami miskonsepi dalam materi gaya gesek statis. Kebanyakan kesalahan yang dilakukan oleh mahasiswa uji adalah mereka menuliskan definisi matematis gaya gesek statis yang bernilai konstan dan tidak bergantung pada gaya "luar" yang bekerja pada suatu benda. Sehingga ketika diberikan permasalahan terkait gaya gesek statis mereka tidak dapat menyelesaikannya dengan baik. Kemungkinan penyebab kesalahan miskonsepsi yang dialami oleh sebagian besar mahasiswa adalah banyaknya literatur yang merumuskan gaya gesek statis secara kurang tepat atau karena perumusan matematis dari gaya gesek statis yang relatif rumit. Oleh karena itu melalui penelitian ini diharapkan ke depannya para guru lebih memperhatikan buku teks yang digunakan oleh para siswa agar tidak menggunakan sumber referensi yang memberikan informasi tidak tepat. Setelah dilakukan pelurusan konsep gaya gesek statis sesuai dengan definisi yang benar melalui penganalogian dengan hukumn Newton II mahasiswa mengalami perbaikan yang signifikan sehingga mereka dapat menyelesaikan konsep gaya gesek statis dengan cukup baik.

\section{DAFTAR PUSTAKA}

De Ambrosis, A., Malgieri, M., Mascheretti, P., \& Onorato, P. (2015). Investigating the role of sliding friction in rolling motion: a teaching sequence based on experiments and simulations. European Journal of Physics, 36(3), p. 035020.

Amontons, G. (1699). De la resistance cause'e dans les machines. Mem l'Academie RA, pp. 257-282. 
Apriliani, S., Budiarti, I. \& Lumbu, A.(2015). Penggunaan analogi dalam pembelajaran fisika melalui metode eksperimen topik aliran arus listrik untuk meningkatkan penguasaan konsep siswa kelas X SMA YPPK Taruna Dharma Kotaraja. Jurnal Pendidikan Fisika dan Keilmuan, 1(1), pp. 14-19. doi:http://dx.doi.org/10.25273/jpfk.v $\underline{1 \mathrm{i} 1.7}$

Balci, S. \& Cakiroglu, J. (2006). Engagement, exploration, explanation, extension, and evaluation (5E) learning cycle and conceptual change text as learning tools. Biochemistry and Molecular Biology Education, 34(3), pp. 199203.

Besson, U. (2013). Historical scientific models and theories as resources for learning and teaching: the case of friction. Science \& Education, 22(5), pp. 1001-1042.

Blass, J. et al., (2015). Dynamic effects in friction and adhesion through cooperative rupture and formation of supramolecular bonds. Nanoscale, 7(17), pp. 7674-7681.

Bryce, T. \& MacMillan, K. (2005). Encouraging conceptual change: the use of bridging analogies in the teaching of action-reaction forces and the 'at rest' condition in physics. International Journal of Science Education, 27 (6), pp. 737-763.

Cepni, S., Sahin, C. \& Ipek, H. (2010). Teaching floating and sinking concepts with different methods and techniques based on the $5 \mathrm{E}$ instructional model. Asia-Pacific Forum on Science Learning and Teaching, 11(2), pp. 1-39.

Chia, T.C. (1996). Common misconceptions in frictional force among university physics students. Teaching and Learning, 16(2), pp.107-116.

Clement, J., Brown, E. \& Zietsman, A. (1989). Not all preconceptions are misconceptions: finding 'anchoring conceptions' for grounding instruction on students intuitions. Int. J. Sci. Educ., 11(5), pp. 554-565.

Coulomb, C. (1773). Sur une application des regles de maximis \& minimis a quelques problemes de statique, relatifs a I'architecture. Memoires de Mathematique \& de Physique, presentes a I' Academie. Royale des Sciences par divers Savans, \& Ius dans ses Assemblees, Volume 7, pp. 343-382.

Esvandiari, E. (2007). Kumpulan Lengkap Rumus Fisika SMA. Jakarta: Puspa Swara.

Grayson, D. (2004). Concept substitution: A teaching strategy for helping students disentangle related physics concepts. Am. J. Phys., 72(8), pp. 1126-1133.

Hammer, D. (1996). More than misconceptions: multiple perpectives on student knowledge and reasoning, and a appropriate role for education research. Am. J. Phys., 64(10), pp. 1316-1325.

Handhika, J., Cari, Suparmi \& Sunarno, W. (2015). External representation to overcome misconception in physics. International Conference on Mathematics, Science, and Education (ICMSE 2015), pp. PE34-37.

Handhika, J., Suparmi, S., \& Cari, C. (2014). Analisis Kesalahan Mahasiswa Dalam Menyelesaikan Hukum Columb. Jurnal Pendidikan Fisika dan Keilmuan (JPFK), 1(1), 29-34. doi:http://dx.doi.org/10.25273/jpfk.v $\underline{1 \mathrm{i} 1.10}$

Hasan, S., Bagayoko, D. \& Kelley, E. (1999). Misconceptions and the certainty of response index (CRI). Phys. Educ., 34(5), pp. 294-299.

Izati, N. (2014). Pintar dan Juara Fisika SMA. Jakarta: PandaMedia.

Kudra, G. \& Awrejcewicz, J. (2016). A smooth model of the resultant friction force on a plane contact area. Journal of Theoretical and Applied Mechanics, 54(3), pp. 909-919. 
Lin, S. \& Singh, C. (2011). Challenges in using analogies. The Physics Teacher, 49(8), pp. 512-513.

Ogborn, J., Kress, G., Martins, I., \& McGillicuddy, K. (1996). Explaining Science in the Classroom. Philadelphia: Open Univesity Press.

Ortiz, S., Rebello, N., Zollman, D. \& Achach, M. (2003). The vocabulary of introductory physics and its implications for learning physics. The Phys. Teach., 41(6), pp. 41-46.

Pinarbasi, T., Canpolat, N., Bayrakceken, S. \& Geban, O. (2006). An investigation of effectiveness of conceptual change text-oriented instruction on students understanding of solution concepts. Research on Science Education, 36(4), pp. 331335.

Popova, E. \& Popov, V. (2015). The research works of Coulomb and Amontons and generalized laws of friction. Friction, 3(2), pp. 183-190.

Redish, E., Scherr, R. \& Tuminaro, J. (2006). Reverse-engineering the solution of a "simple" physics problem: why learning physics is harder than it looks. The Phys. Teach., 44(5), pp. 293-300.

Sharma, S. \& Sharma, K. (2007). Concepts of force and frictional force: the influence of preconceptions on learning across different levels. Physics Education, 42(5), pp. 516521.
Sugiyono, V. (2009). Jurus Sakti Menaklukkan Fisika SMA 1, 2, \& 3. Surabaya: LinguaKata.

Supomo, T. (2007). Panduan UNAS Fisika SMA. Pustaka Widyatama: Yogyakarta.

Syuhendri, S., Jaafar, R., \& Yahya, R. A. S. (2014). Analysis of Physics Education Department Students' Misconceptions on Other Influences on Motion.

Tiandho, Y., (2016). Modifikasi distribusi massa pada suatu objek simetri bola. Jurnal Pendidikan Fisika IV(2), pp. 76-85.

Trianggono, M. (2017). Analisis Kausalitas Pemahaman Konsep Dengan Kemampuan Berpikir Kreatif Siswa Pada Pemecahan Masalah Fisika. Jurnal Pendidikan Fisika dan Keilmuan (JPFK), 3(1), 1-12. doi:http://dx.doi.org/10.25273/jpfk.v $\underline{3 i 1.874}$

Young, H., Freedman, R. \& Ford, A. (2012). Sears and Zemansky's University Physics. 13th ed. USA: AddisonWesley.

Yuruk, N. (2007). The effect of supplementing instruction with conceptual change texts on student's conceptions of electrochemical cells. Journal of Science Education Technology, 16(6), pp. 515-523. 